\title{
Purification and Characterization of $\beta$-Xylosidase from Paenibacillus sp. DG-22
}

Tae Hyeong Lee, Pyung Ok Lim and Yong-Eok Lee*

Department of Biotechnology, Dongguk University, Kyungju, Kyongbuk 780-714, Korea

${ }^{1}$ Department of Science Education, Cheju National University, Jeju-Si, Jeju 690-756, Korea

Received October 1, 2007 / Accepted October 18, 2007

\begin{abstract}
An intracellular $\beta$-xylosidase from Paenibacillus sp. DG-22 was purified to homogeneity by ion-exchange, hydrophobic interaction and gel-filtration chromatography. The molecular weight of the enzyme was measured to be 156,000 by gel filtration and 80,000 by SDS-PAGE, indicating that the enzyme consisted of two identical subunits. The purified enzyme exhibited maximum activity at $65^{\circ} \mathrm{C}$ and $\mathrm{pH} 5.5$. It retained $80 \%$ of its initial activity up to $60 \mathrm{~min}$ at $60^{\circ} \mathrm{C}$ and had a half-life of $25 \mathrm{~min}$ at $65^{\circ} \mathrm{C}$. The enzyme was highly specific for $\mathrm{pNPX}$ as the substrate. It showed little or no activity against other $p$-nitrophenyl glycosides and xylans. The $K_{\mathrm{m}}$ and $V_{\max }$ for pNPX was $0.53 \mathrm{mM}$ and $3.18 \mathrm{U} / \mathrm{mg}$ protein, respectively. The $\beta$-xylosidase was strongly inhibited by $\mathrm{Ag}^{+}, \mathrm{Fe}^{2+}, \mathrm{Hg}^{2+}$ and $\mathrm{Zn}^{2+}$ and slightly activated by DTT. The hydrolysis product from xylobiose, xylotriose, and xylotetraose was xylose.
\end{abstract}

Key words - Paenibacillus sp., $\beta$-xylosidase, purification

\section{Introduction}

Xylan is the major component of plant hemicellulose and the second most abundant renewable polysaccharide in nature. It is a heterogeneous polysaccharide consisting of a main chain of $\beta$-1,4-linked D-xylose residues with arabinofuranose, glucuronic acid and acetyl side groups. The composition and structure of xylan vary according to the source [4]. Complete breakdown of xylan requires the cooperative action of several hydrolytic enzymes of which endoxylanase and $\beta$-xylosidase are the most important [2]. Endoxylanase (1,4- $\beta$-D-xylan xylanohydrolase, EC 3.2.1.8) randomly cleaves off the $\beta-1,4$ bonds in the xylan backbone to yield xylo-oligosaccharides. $\beta$-Xylosidase $(1,4-\beta$-D-xylan xylohydrolase, EC 3.2.1.37) hydrolyzes xylobiose and short chain xylo-oligosaccharides from the non-reducing end to produce xylose, which can then be used as a fermentation feed stock for various useful products such as xylitol and ethanol $[22,23]$. It also plays an important role in relieving the end product inhibition of endoxylanase, therefore it is essential for complete breakdown of xylan [17]. Accessory enzymes, such as $\alpha$-arabinofuranosidase, $\alpha$-glucuronidase and acetylxylan esterase are also required for the removal of side groups [4].

Although many fungal $\beta$-xylosidases have been studied $[8,18]$, only a few reports are available on the purification

\section{*Corresponding author}

Tel : +82-54-770-2226, Fax : +82-54-770-2287

E-mail : yelee@mail.dongguk.ac.kr and characterization of bacterial $\beta$-xylosidases $[10,12,19]$, including those expressed in E. coli [7] and Saccharomyces cerevisiae [5]. The $\beta$-xylosidases are intracellular in most bacteria and yeasts, whereas those of fungi are secreted in to culture media [18]. $\beta$-Xylosidase have been classified into families 39,43 and 52 of glycosyl hydrolases, based on their amino acid sequence similarities [6].

Paenibacillus sp. DG-22, a moderately thermophilic bacterium isolated from timber yard soil, grows actively on xylan as a sole carbon source and does not have cellulase activity [11]. We previously reported the purification and characterization of endoxylanases [15] and cloning of xylanase A gene from this bacterium [13]. The synthesis of $\beta$-xylosidase from Paenibacillus sp. DG-22 was induced by xylan and methyl $\beta$-D-xylopyranoside but repressed by glucose and xylose [14]. The objective of this work is to purify and characterize the intracellular $\beta$-xylosidase from Paenibacillus sp. DG-22.

\section{Materials and Methods}

\section{Chemicals}

Beechwood xylan, birchwood xylan, oat spelts xylan, methyl $\beta$-D-xylopyranoside, $p$-nitrophenyl glycosides and xylose were purchased from Sigma Chemical Co. (St. Louis, MO, USA). Xylobiose $\left(X_{2}\right)$, xylotriose $\left(X_{3}\right)$ and xylotetraose $\left(X_{4}\right)$ were obtained from MegaZyme (North Rocks, Australia). Q-Sepharose, Sephacryl S-200 and Sephacryl S-300 were purchased from Amersham Pharmacia Biotech (Piscataway, NJ, USA). Butyl Spherilose was obtained from 
Isco Inc. (Lincoln, NE, USA). The molecular mass markers were from Bio-Rad Laboratories (Hercules, CA, USA). All other chemicals used were of reagent grade.

\section{Strain and culture conditions}

Paenibacillus sp. DG-22 [11] was used for enzyme production. It was cultivated aerobically at $45^{\circ} \mathrm{C}$ for $18 \mathrm{hr}$ in a $2 x$ YT medium $(1.6 \%$ tryptone, $1 \%$ yeast extract and $0.5 \% \mathrm{NaCl}, \mathrm{pH} 6.0)$ supplemented with $1 \%(\mathrm{w} / \mathrm{v})$ methyl $\beta$-D-xylopyranoside.

\section{Enzyme and protein assay}

$\beta$-Xylosidase activity was measured by a spectrophotometric method with $p$-nitrophenyl $\beta$-D-xylopyranoside $(\mathrm{pNPX})$ as the substrate. The reaction mixture, composed of $1 \mathrm{mM}$ pNPX, $50 \mathrm{mM}$ sodium acetate (pH 5.5), and diluted enzyme in $0.5 \mathrm{ml}$ reaction volume, was incubated at $60^{\circ} \mathrm{C}$ for $10 \mathrm{~min}$. The reaction was stopped by the addition of $1.0 \mathrm{ml}$ of $1.0 \mathrm{M}$ sodium carbonate and the nitrophenol released was measured as absorbance at $410 \mathrm{~nm}$. A standard curve was prepared by using $p$-nitrophenol. One unit of $\beta$-xylosidase activity was defined as the amount of enzyme which released $1 \mu \mathrm{mol}$ of $p$-nitrophenol in $1 \mathrm{~min}$. Other $p$-nitrophenol derivatives of sugars were also tested as substrates under the same conditions.

Protein concentration was determined by the Bradford method [3] with the Bio-Rad protein assay reagent (Bio-Rad Laboratories) using bovine serum albumin as the standard.

\section{Enzyme purification}

Unless otherwise stated, all steps were conducted at room temperature. Cells grown on one liter of $2 x$ YT medium supplemented with $1 \%(w / v)$ methyl $\beta$-D-xylopyranoside were suspended in $30 \mathrm{ml}$ of $20 \mathrm{mM}$ sodium phosphate ( $\mathrm{pH} 7.0)$, and sonicated on ice for $20 \mathrm{~min}$ with a Branson sonifier (250 watts, $40 \%$ pulsed mode). The supernatant obtained by centrifugation $(12,000 \mathrm{x} \mathrm{g}, 20 \mathrm{~min})$ was used as the crude enzyme preparation.

(i) Ion-exchange chromatography: The crude enzyme solution was put on a Q-Sepharose column $(2.5 \times 18 \mathrm{~cm})$ pre-equilibrated with $20 \mathrm{mM}$ sodium phosphate buffer $(\mathrm{pH}$ 7.0). The column was washed with the same buffer using two-folds volume of bed volume and absorbed proteins were eluted with a linear gradient of 0 to $0.8 \mathrm{M} \mathrm{NaCl}$ in the same buffer at a flow rate of $1.0 \mathrm{ml} / \mathrm{min}$. The active $\beta$-xylosidase peak fractions were concentrated by ultra- filtration using a YM30 membrane (Amicon, Beverly, USA) and dialyzed against $20 \mathrm{mM}$ sodium phosphate buffer $(\mathrm{pH}$ 7.0) containing $0.6 \mathrm{M}$ ammonium sulfate.

(ii) Hydrophobic interaction chromatography: The dialyzed enzyme solution was then applied to a Butyl Spherilose column $(2.5 \times 5 \mathrm{~cm})$, previously equilibrated with $20 \mathrm{mM}$ sodium phosphate buffer $(\mathrm{pH} 7.0)$ containing $0.6 \mathrm{M}$ ammonium sulfate. The column was washed with the same buffer and eluted with decreasing ammonium sulfate gradient $(0.6-0 \mathrm{M})$ at a flow rate of $0.8 \mathrm{ml} / \mathrm{min}$. The active fractions were dialyzed overnight against $50 \mathrm{mM}$ sodium acetate buffer (pH 5.5) containing $0.2 \mathrm{M} \mathrm{NaCl}$ and concentrated by ultrafiltration.

(iii) Gel-filtration chromatography: The concentrated enzyme solution was applied to a column of Sephacryl S-300 $(2.5 \times 50 \mathrm{~cm})$ pre-equilibrated with $50 \mathrm{mM}$ sodium acetate buffer (pH 5.5) containing $0.2 \mathrm{M} \mathrm{NaCl}$. The enzyme was eluted with the same buffer at a flow rate of 0.24 $\mathrm{ml} / \mathrm{min}$. Active fractions were pooled and concentrated by ultrafiltration.

\section{Estimation of molecular weight}

The apparent molecular weight of the native enzyme was determined by gel filtration on a Sephacryl S-200 column $(1.0 \times 50 \mathrm{~cm})$. The molecular weight determination under denaturing condition was performed by sodium dodecyl sulfate-polyacrylamide gel electrophoresis (SDS-PAGE) according to Laemmli [9]. Gel (12.5\%) was stained with Coomassie Brilliant Blue R-250.

\section{Effect of $\mathrm{pH}$ and temperature}

The effect of $\mathrm{pH}$ on the enzyme activity was estimated using assay in Mcllvaine buffer $\left(0.2 \mathrm{M} \mathrm{Na}_{2} \mathrm{HPO}_{4}-0.1 \mathrm{M}\right.$ citric acid) at $\mathrm{pH}$ values from $\mathrm{pH} 3.0$ to 7.5 at $60^{\circ} \mathrm{C}$. The effect of temperature on the activity was assayed by incubating $0.1 \mathrm{U}$ of the purified enzyme in sodium acetate buffer (pH 5.5) at different temperatures in the range of $30^{\circ} \mathrm{C}$ to $85^{\circ} \mathrm{C}$. The thermostability of the purified $\beta$-xylosidase was monitored by preincubating $0.1 \mathrm{U}$ of the enzyme in the $\mathrm{ab}$ sence of substrate at $60^{\circ} \mathrm{C}$ or $65^{\circ} \mathrm{C}$. After being heated for the appropriate time interval, samples were cooled on ice and the residual enzyme activities were measured under standard assay conditions.

\section{Effects of metal ions and other reagents}

Various metal ions $(1 \mathrm{mM})$, other reagents $(1 \mathrm{mM})$ or 
sugars $(250 \mathrm{mM})$ were added to the standard enzymatic reaction mixtures containing $0.1 \mathrm{U}$ of the purified enzyme in order to study their effects on $\beta$-xylosidase activity. Enzyme activities were then measured under standard assay conditions.

\section{Kinetic parameters}

The kinetic parameters of $\beta$-xylosidase for $\mathrm{pNPX}$ were determined by incubating the purified enzyme with different amounts of pNPX (0.2 to $2 \mathrm{mM}$ ) in sodium acetate buffer (pH 5.5) at $60^{\circ} \mathrm{C}$. For each assay, ten different substrate concentrations were used in three independent experiments. The values of the Michaelis constant $\left(K_{\mathrm{m}}\right)$ and maximum velocity $\left(V_{\max }\right)$ were determined from Lineweaver-Burk plot.

\section{Hydrolysis studies}

The hydrolysis products from xylo-oligosaccharides $\left(X_{2}\right.$, $X_{3}$ and $X_{4}$ ) by purified $\beta$-xylosidase were analyzed by thin-layer chromatography (TLC). The hydrolysis was carried out with $1 \mathrm{U}$ of the purified $\beta$-xylosidase and $100 \mu \mathrm{g}$ of xylo-oligosaccharides in $100 \mu \mathrm{l}$ of $50 \mathrm{mM}$ sodium acetate buffer $\left(\mathrm{pH} \mathrm{5.5)}\right.$ at $60^{\circ} \mathrm{C}$ for $30 \mathrm{~min}$. Equal amounts of the aliquots were removed periodically and the reaction was stopped by placing the mixture in boiling water for 10 $\min$. A $1 \mu \mathrm{l}$ portion of each sample was spotted onto a silica gel plate $60 \mathrm{~F}_{254}$ (Merck, Darmstadt, Germany) and chro- matographed in a solvent system containing $\mathrm{n}$-butanol/acetic acid/water $(2: 1: 1, \mathrm{v} / \mathrm{v} / \mathrm{v})$ at room temperature. The sugars on the plate were visualized by spraying the plate with $20 \%$ sulfuric acid and $0.1 \%$ orcinol in methanol, followed by heating at $110^{\circ} \mathrm{C}$ for $5 \mathrm{~min}$.

\section{Results and Discussion}

\section{Purification of $\beta$-xylosidase}

An intracellular $\beta$-xylosidase was purified to homogeneity from the cell extract of Paenibacillus sp. DG-22 grown on $2 x$ YT medium containing $1 \%(w / v)$ methyl $\beta$-Dxylopyranoside. The cell extract was fractionated by ion-exchange chromatography on Q-Sepharose. $\beta$-Xylosidase activity was eluted at $0.5 \mathrm{M} \mathrm{NaCl}$ using a $0-0.8 \mathrm{M} \mathrm{NaCl}$ gradient in $20 \mathrm{mM}$ sodium phosphate buffer ( $\mathrm{pH}$ 7.0). Active fractions were concentrated by ultrafiltration and dialyzed against $20 \mathrm{mM}$ sodium phosphate buffer ( $\mathrm{pH} 7.0$ ) containing $0.6 \mathrm{M}$ ammonium sulfate. In the second step the dialyzed enzyme solution was loaded onto a Butyl Spherilose column pre-equilibrated with the same buffer. To obtain purified $\beta$-xylosidase, a further purification step with a gel-filtration chromatography on a Sephacryl S-300 column was performed. A summary of these three-step purification procedures is shown in Table 1. It was purified 64-fold with a $4.9 \%$ yield. The purified enzyme was shown to be homogeneous by the detection of a single protein band on SDS-PAGE (Fig. 1).

\section{Molecular weights of $\beta$-xylosidase}

The molecular mass of $\beta$-xylosidase in native state, based on the gel filtration chromatography, was $156 \mathrm{kDa}$ (data not shown). SDS-PAGE analysis showed a single band with a molecular mass of about $80 \mathrm{kDa}$ (Fig. 1, lane 4), suggesting that the enzyme consisted of two identical subunits. The molecular weight of $\beta$-xylosidase from Paenibacillus sp. DG-22 is within the range reported for other bacterial $\beta$-xylosidases. Bacterial $\beta$-xylosidases were

Table 1. Purification of the $\beta$-xylosidase from Paenibacillus sp. DG-22

\begin{tabular}{lrrrrr}
\hline \multicolumn{1}{c}{ Step } & $\begin{array}{c}\text { Total } \\
\text { activity } \\
(\mathrm{U})\end{array}$ & $\begin{array}{c}\text { Total } \\
\text { protein } \\
(\mathrm{mg})\end{array}$ & $\begin{array}{c}\text { Specific } \\
\text { activity } \\
(\mathrm{U} / \mathrm{mg})\end{array}$ & $\begin{array}{c}\text { Purifi- } \\
\text { cation } \\
\text { (folds) }\end{array}$ & $\begin{array}{c}\text { Yield } \\
(\%)\end{array}$ \\
\hline Sonic extract & 372.4 & 116.4 & 3.2 & 1.0 & 100 \\
Q-Sepharose & 237.8 & 11.1 & 21.4 & 6.7 & 63.8 \\
Butyl Spherilose & 83.8 & 0.57 & 146.0 & 45.6 & 22.5 \\
Sephacryl S-300 & 18.4 & 0.09 & 204.4 & 63.9 & 4.9 \\
\hline
\end{tabular}

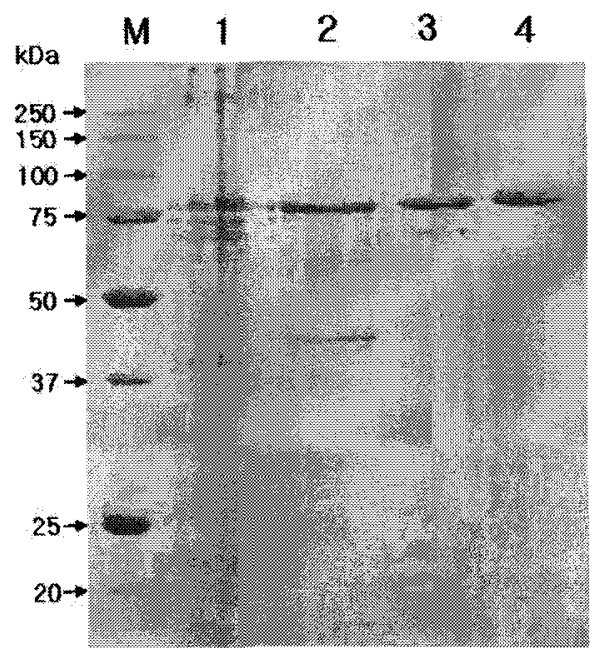

Fig. 1. SDS-PAGE analysis of the purified $\beta$-xylosidase from Paenibacillus sp. DG-22. Lane M, molecular mass marker; Lane 1, sonic extract; lane 2, fraction after Q-Sepharose; lane 3, fraction after Butyl Spherilose; lane 4, fraction after Sephacryl S-300 column. 

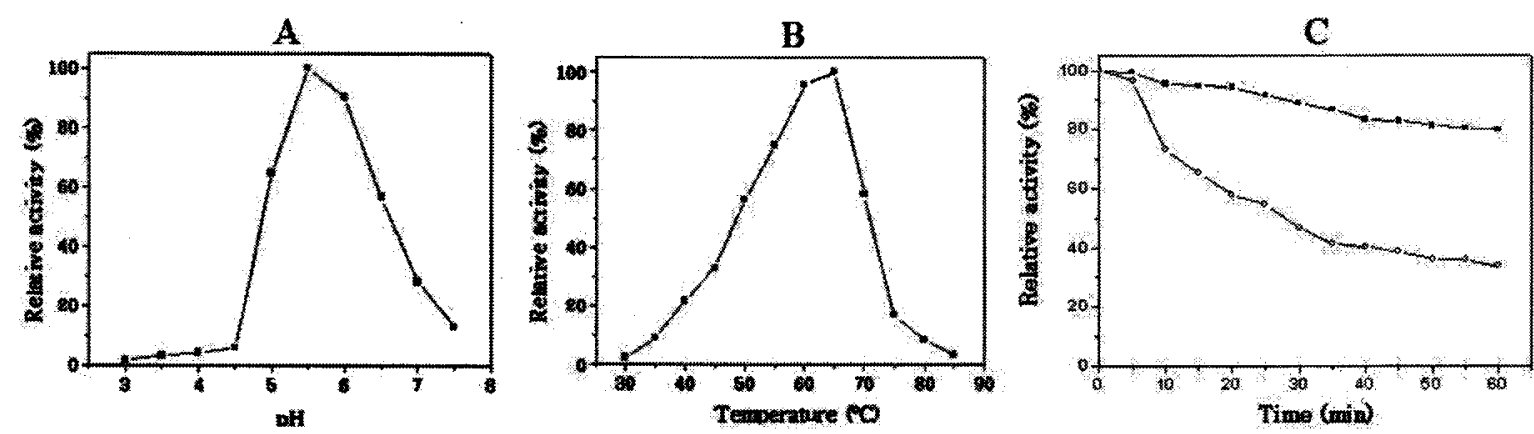

Fig. 2. Effects of $\mathrm{pH}(\mathrm{A})$ and temperature (B) on the activity of purified $\beta$-xylosidase from Paenibacillus sp. DG-22. The activities at the optimal $\mathrm{pH}$ and the optimal temperature were defined as $100 \%$. Thermostability of purified enzyme at $\mathrm{pH} 5.5$ in the absence of substrate $(C)$. Residual activity was monitored at various times after incubation at $60^{\circ} \mathrm{C}(\square)$ or $65^{\circ} \mathrm{C}(\mathrm{O})$. The initial activity was defined as $100 \%$.

reported either as an homodimer of subunits having a molecular weight of $75-85 \mathrm{kDa}[10,16,19]$ or an heterotrimer comprising one subunit of $63 \mathrm{kDa}$ and two of $85 \mathrm{kDa}$ in the case of Clostridium acetobutylicum [12]. Molecular weights ranging from $39.5 \mathrm{kDa}$ to $411 \mathrm{kDa}$ have been reported for fungal $\beta$-xylosidases, which behaved as a monomeric, dimeric, or tetrameric species [18].

\section{Effects of $\mathrm{pH}$ and temperature on $\beta$-xylosidase activity}

The physicochemical properties of $\beta$-xylosidase were determined with the purified enzyme. The enzyme had a rather sharp optimal $\mathrm{pH}$ and temperature. The $\mathrm{pH}$ optimum for hydrolysis of $\mathrm{pNPX}$ was 5.5 , with $5 \%$ activity at $\mathrm{pH} 4.5$ and $12 \%$ activity at $\mathrm{pH} 7.5$ (Fig. 2A). The pH optimum is similar to those of other bacterial $\beta$-xylosidases $[10,16,19]$. The optimum temperature for activity was $65^{\circ} \mathrm{C}$ with activity decreasing rapidly at higher temperature (Fig. 2B). The enzyme showed no activity at temperatures below $30^{\circ} \mathrm{C}$ and above $85^{\circ} \mathrm{C}$. To examine the thermostability of the enzyme, $\beta$-xylosidase was incubated at $60^{\circ} \mathrm{C}$ or $65^{\circ} \mathrm{C}$ for up to $60 \mathrm{~min}$ in the absence of substrate, and the residual activities were assayed (Fig. 2C). The purified enzyme was fairly stable at $60^{\circ} \mathrm{C}$. It retained $80 \%$ of its initial activity up to $60 \mathrm{~min}$ of incubation. The enzymatic activity decreased significantly at $65^{\circ} \mathrm{C}$. The half-life of the enzyme at $65^{\circ} \mathrm{C}$ was about $25 \mathrm{~min}$.

\section{Substrate specificity}

The hydrolytic properties of $\beta$-xylosidase toward various $p$-nitrophenyl glycosides were determined. The enzyme was most active against pNPX (Table 2). Lower or no activity was observed with the other substrates tested. Substrate
Table 2. Hydrolysis of various $p$-nitrophenyl glycosides by the purified $\beta$-xylosidase

\begin{tabular}{lc}
\hline \multicolumn{1}{c}{ Substrate $(1 \mathrm{mM})$} & Relative activity (\%) \\
\hline$p$-nitrophenyl- $\beta$-D-xylopyranoside & 100.0 \\
$p$-nitrophenyl- $\alpha$-D-xylopyranoside & 3.97 \\
$p$-nitrophenyl- $\alpha$-L-arabinofuranoside & 0.43 \\
$p$-nitrophenyl- $\alpha$-L-arabinopyranoside & 0.11 \\
$p$-nitrophenyl- $\beta$-L-arabinopyranoside & 0.11 \\
$p$-nitrophenyl- $\beta$-D-fucopyranoside & 0 \\
$p$-nitrophenyl- $\alpha$-D-glucopyranoside & 0 \\
$p$-nitrophenyl- $\beta$-D-glucopyranoside & 0 \\
$p$-nitrophenyl- $\beta$-D-mannoopyranoside & 0 \\
\hline
\end{tabular}

ambiguity of $\beta$-xylosidase has been reported for several $\beta$ xylosidases. In Trichoderma reesei [17], Butyrivibrio fibrisolvens [21], Thermomonospora fusca [1] and Thermoanaerobacter ethanolicus [19] the purified $\beta$-xylosidases also showed $\alpha$-arabinofuranosidase activity. The purified enzyme did not degrade oat spelts xylan, beechwood xylan and birchwood xylan (data not shown).

\section{Effects of metal ions and reagents on the enzyme activity}

The activity of $\beta$-xylosidase was measured under standard assay conditions in the presence of metal ions and other reagents (Table 3). DTT increased the enzyme activity by $21 \%$. On the other hand, $\mathrm{AgCl}$ completely inhibited the $\beta$-xylosidase activity at a concentration of $1 \mathrm{mM}$. Addition of $1 \mathrm{mM} \mathrm{FeCl}, \mathrm{HgCl}_{2}$ or $\mathrm{ZnCl}_{2}$ decreased the enzyme activity by $55 \%, 90 \%$ and $70 \%$, respectively. The presence of EDTA did not affect the activity. These results suggest that metal ions are not necessary for the enzyme activity. The effects of arabinose, galactose, and xylose on the activity of $\beta$-xylosidase were also investigated. Most of $\beta$-xylosidases 
Table 3. Effect of metal ions and some compounds on purified $\beta$-xylosidase

\begin{tabular}{ccc}
\hline Compounds & $\begin{array}{c}\text { Concentration } \\
(\mathrm{mM})\end{array}$ & $\begin{array}{c}\text { Residual activity } \\
\text { (\%) }\end{array}$ \\
\hline Control & & 100.0 \\
$\mathrm{DTT}$ & 1 & 120.6 \\
EDTA & 1 & 103.3 \\
$\beta$-mercaptoethanol & 1 & 102.1 \\
$\mathrm{AgCl}$ & 1 & 0 \\
$\mathrm{CaCl}_{2}$ & 1 & 102.4 \\
$\mathrm{CoCl}_{2}$ & 1 & 96.8 \\
$\mathrm{CuCl}_{2}$ & 1 & 83.7 \\
$\mathrm{FeCl}_{2}$ & 1 & 45.1 \\
$\mathrm{HgCl}_{2}$ & 1 & 9.8 \\
$\mathrm{KCl}$ & 1 & 95.1 \\
$\mathrm{MgCl}_{2}$ & 1 & 97.6 \\
$\mathrm{MnCl}_{2}$ & 1 & 97.3 \\
$\mathrm{RbCl}$ & 1 & 97.1 \\
$\mathrm{ZnCl}_{2}$ & 1 & 30.1 \\
Arabinose & 250 & 74.9 \\
$\mathrm{Galactose}^{\text {Xylose }}$ & 250 & 93.3 \\
\hline
\end{tabular}

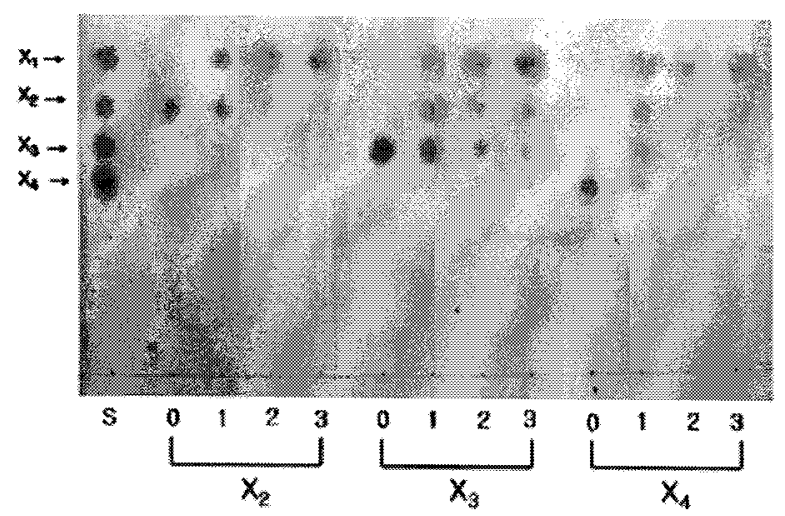

Fig. 3. Thin layer chromatography of the hydrolysis products from xylo-oligosaccharides by purified $\beta$-xylosidase. The purified enzymes were incubated with xylobiose $\left(X_{2}\right)$, xylotriose $\left(X_{3}\right)$, and xylotetraose $\left(X_{4}\right)$ in $50 \mathrm{mM}$ sodium acetate buffer ( $\mathrm{pH} 5.5)$ at $60^{\circ} \mathrm{C}$ for $0 \mathrm{~min}$ (lane 0$), 10 \mathrm{~min}$ (lane 1), $20 \mathrm{~min}$ (lane 2), and $30 \mathrm{~min}$ (lane 3), respectively. The standards (lane $S$ ) used were xylose $\left(X_{1}\right)$, xylobiose $\left(X_{2}\right)$, xylotriose $\left(X_{3}\right)$, and xylotetraose $\left(X_{4}\right)$.

studied were reported to be inhibited by xylose and some other monosaccharides such as arabinose and galactose $[4,7]$. As shown in Table 3, the enzyme activity decreased by $25 \%, 7 \%$ and $44 \%$ with arabinose, galactose and xylose, respectively at a $250 \mathrm{mM}$ concentration.

\section{Kinetic analysis of $\beta$-xylosidase}

The kinetic parameters of $\beta$-xylosidase were investigated using pNPX as a substrate. The purified enzyme exhibited a typical Michaelis-Menten kinetics, with $K_{\mathrm{m}}$ and $V_{\max }$ values of $0.53 \pm 0.03 \mathrm{mM}$ and $3.18 \pm 0.05 \mathrm{U} / \mathrm{mg}$ protein, respectively. The $K_{\mathrm{m}}$ value was close to reported $K_{\mathrm{m}}$ value of $\beta$-xylosidases from Bacillus sp. $[10,20]$.

\section{Hydrolysis of xylo-oligosaccharides}

In order to confirm the mode of action of the $\beta$-xylosidase from Paenibacillus sp. DG-22, hydrolysis products from xylo-oligosaccharides $\left(X_{2}, X_{3}, X_{4}\right)$ were analyzed by TLC (Fig. 3). The enzyme released xylose from all substrates suggesting that it is a true $\beta$-xylosidase.

\section{Acknowledgement}

This work is supported by the Dongguk University Research Fund.

\section{References}

1. Bachmann S. L. and A. J. MacCarthy. 1989. Purification and characterization of a thermostable $\beta$-xylosidase from Thermomonospora fusca. J. Gen. Microbiol. 135, 293-299.

2. Biely, P. 1985. Microbial xylanolytic systems. Trends Biotechnol. 3, 286-290.

3. Bradford, M. M. 1976. A rapid and sensitive method for quantitation of microgram quantities of protein utilizing the principle of protein-dye binding. Anal. Biochem. 72, 248-256.

4. Coughlan, M. P. and G. P. Hazlewood. 1993. $\beta-1,4-X y l a n$ degrading enzyme systems: biochemistry, molecular biology and applications. Biotechnol. Appl. Biochem. 17, 259-289.

5. Heo, S.-Y., J.-K. Kim, Y.-M. Kim and S.-W. Nam. 2004. Xylan hydrolysis by treatment with endoxylanase and $\beta$ xylosidase expressed in yeast. J. Microbiol. Biotechnol. 14, 171-177.

6. Henrissat, B. and A. Bairoch. 1996. Updating the sequence-based classification of glycosyl hydrolases. Biochem. J. 316, 695-696.

7. Jung, K. H., Y. C. Chun, J.-C. Lee, S.-H. Park and K.-H. Yoon. 1998. Purification and characterization of Bacillus sp. KK-1 $\beta$-xylosidase from a recombinant Escherichia coli. J. Microbiol. Biotechnol. 8, 258-263.

8. Kim, B. G., B.-R. Jung, J. G. Jung, H.-G. Hur and J.-H. Ahn. 2004. Purification and characterization of $\beta$-xylosidase from Trichoderma sp. SY. J. Microbiol. Biotechnol. 14, 643-645.

9. Laemmli, U. K. 1970. Cleavage of structural proteins during the assembly of the head of bacteriophage T4. Nature 227, 680-685.

10. Lama, L., V. Calandrelli, A. Gambacorta and B. Nicolaus. 2004. Purification and characterization of thermostable xy- 
lanase and $\beta$-xylosidase by the thermophilic bacterium Bacillus thermantarcticus. Res. Microbiol. 155, 283-289.

11. Lee, Y.-E. 2004. Isolation and characterization of thermostable xylanase- producing Paenibacillus sp. DG-22. Kor. J. Microbiol. Biotechnol. 32, 22-28.

12. Lee, S. F. and C. W. Forsberg. 1987. Isolation and some properties of a $\beta$-D-xylosidase from Clostridium acetobutylicum ATCC 824. Appl. Environ. Microbiol. 53, 651-654.

13. Lee, T. H., P. O. Lim and Y.-E. Lee. 2007. Cloning, characterization, and expression of xylanase $\mathrm{A}$ gene from Paenibacillus sp. DG-22 in Escherichia coli. J. Microbiol. Biotechnol. 17, 29-36.

14. Lee, T. H., P. O. Lim and Y.-E. Lee. 2007. Regulation of $\beta$-xylosidase biosynthesis in Paenibacillus sp. DG-22. J. Life Sci. 17, 407-411.

15. Lee, Y.-E. and P. O. Lim. 2004. Purification and characterization of two thermostable xylanases from Paenibacillus sp. DG-22. J. Microbiol. Biotechnol. 14, 1014-1021.

16. Nanmori, T., T. Watanabe, R. Shinke, A. Kohno and Y. Kawamura. 1990. Purification and properties of thermostable xylanase and $\beta$-xylosidase produced by a newly isolated Bacillus stearothermophilus strain. J. Bacteriol. 172, 6669-6672.

17. Poutanen, K. and J. Puls. 1988. Characteristics of
Trichoderma reesei $\beta$-xylosidase and its use in the hydrolysis of solubilized xylans. Appl. Microbiol. Biotechnol. 28, 425-432.

18. Saha, B. C. 2003. Hemicellulose bioconversion. I. Ind. Microbiol. Biotechnol. 30, 279-291.

19. Shao, W. and J. Wiegel. 1992 Purification and characterization of a thermostable $\beta$-xylosidase from Thermoanaerobacter ethanolicus. J. Bacteriol. 174, 5848-5853.

20. Sung, N. K., I. S. Kang, H. K. Chun, T. Akiba and K. Horikoshi. 1987. Purification and properties of extracellular $\beta$-xylosidase from thermophilic alkalophilic Bacillus sp. K-17. Kor. J. Appl. Microbiol. Biotechnol. 15, 267-272.

21. Utt, E. A., C. K. Eddy, K. F. Keshav and L. O. Ingram. 1991. Sequencing and expression of the Butyrivibrio fibrisolvens $x y l B$ gene encoding a novel bifunctional protein with $\beta$-D-xylosidase and $\alpha$-L-arabinofuranosidase activities. Appl. Environ. Microbiol. 57, 227-234.

22. Ward, O. P. and M. Moo-Young. 1989. Enzymatic degradation of cell wall and related plant polysaccharides. Crit. Rev. Biotechnol. 8, 237-274.

23. Wong, K. K. Y. and J. N. Saddler. 1988. Multiplicity of $\beta-1$, 4-xylanase in microorganisms: functions and applications. Microbiol. Reo. 52, 305-317.

\title{
초록 : Paenibacillus sp. DG-22로부터 $\beta$-xylosidase의 정제 및 특성분석
}

\author{
이태형 · 임평옥 ${ }^{1} \cdot$ 이용억* \\ (동국대학교 과학기술대학 생명공학과, ${ }^{1}$ 제주대학교 사범대학 과학교육과)
}

Paenibacillus sp. DG-22로부터 세포내 효소인 $\beta$-xylosidase가 이온교환, 소수성 상호작용, 겔여과 크래마토그래 피에 의해 순수하게 정제되었다. 이 효소의 분자량은 겔여과에 의해서는 156,000으로, SDS-PAGE에 의해서는 80,000 으로 측정되었는데 이젓은 이 효소가 동일한 두 소단위로 구성되어 있음을 나타낸다. 정제된 효소는 $65^{\circ} \mathrm{C}$ 와 $\mathrm{pH} 5.5$ 에서 최대 활성을 나타내었다. 이 효소는 $60^{\circ} \mathrm{C}$ 에서 60 분 까지 초기 활성의 $80 \%$ 를 유지하였고 $65^{\circ} \mathrm{C}$ 에서 25분의 반감기를 가지고 있었다. 이 효소는 기질로서 $\mathrm{pNPX}$ 에 매우 특이적이었고 다른 p-nitrophenyl 글리코시드 들과 자일란에는 활성을 나타내지 않았다. $\mathrm{pNPX}$ 에 대한 $K_{\mathrm{m}}$ 과 $V_{\max }$ 는 각각 $0.53 \mathrm{mM}$ 과 $3.18 \mathrm{U} / \mathrm{mg}$ 단백질이었다. 이 $\beta$-xylosidase는 $\mathrm{Ag}^{+}, \mathrm{Fe}^{2+}, \mathrm{Hg}^{2+}$ 및 $\mathrm{Zn}^{2+}$ 에 의해 강하게 억제되었으며 DTT에 의해서 약간 활성화되었다. 자일 로바이오스, 자일로트라이오스 및 자일로테트라오스로부터의 가수분해 산물은 자일로오스이었다. 